NBER WORKING PAPER SERIES

\title{
PERSONAL BANKRUPTCY AND THE LEVEL OF ENTREPRENEURIAL ACTIVITY
}

\author{
Wei Fan \\ Michelle J. White \\ Working Paper 9340 \\ http://www.nber.org/papers/w9340 \\ NATIONAL BUREAU OF ECONOMIC RESEARCH \\ 1050 Massachusetts Avenue \\ Cambridge, MA 02138 \\ November 2002
}

We are grateful for comments from Mitchell Berlin, Charlie Brown, David de Meza, Alan Schwartz, and participants at seminars at Berkeley, Columbia, Michigan, Tilburg, the Philadelphia Fed, the Bank of England, the ALEA Annual Conference, and the NBER Summer Institute in Law and Economics. The N.S.F. provided financial support under grant number NSF-SBR-9617712. The views expressed herein are those of the authors and not necessarily those of the National Bureau of Economic Research.

(C) 2002 by Wei Fan and Michelle J. White. All rights reserved. Short sections of text, not to exceed two paragraphs, may be quoted without explicit permission provided that full credit, including $\odot$ notice, is given to the source. 
Personal Bankruptcy and the Level of Entrepreneurial Activity

Wei Fan and Michelle J. White

NBER Working Paper No. 9340

November 2002

JEL No. E6, K2, M13, L5

$\underline{\text { ABSTRACT }}$

The U.S. personal bankruptcy system functions as a bankruptcy system for small businesses as well as consumers, because debts of non-corporate firms are personal liabilities of the firms' owners. If the firm fails, the owner has an incentive to file for bankruptcy, since both business debts and the owner's personal debts will be discharged. In bankruptcy, the owner must give up assets above a fixed exemption level. Because exemption levels are set by the states, they vary widely.

We show that higher bankruptcy exemption levels benefit potential entrepreneurs who are risk averse by providing partial wealth insurance and therefore the probability of owning a business increases as the exemption level rises. We test this prediction and find that the probability of households owning businesses is $35 \%$ higher if they live in states with unlimited rather than low exemptions. We also find that the probability of starting a business and the probability of owning a corporate rather than non-corporate business are higher for households that live in high exemption states.

Wei Fan

J.D. Powers, Inc.

5435 Corporate Drive, Suite 300

Troy, MI 48098
Michelle J. White

Department of Economics

University of California, San Diego

9500 Gilman Dr.

La Jolla CA 92093-0508

and NBER

miwhite@ucsd.edu 


\section{Personal Bankruptcy and the Level of Entrepreneurial Activity ${ }^{1}$}

Wei Fan and Michelle J. White

The U.S. personal bankruptcy system is primarily intended as a bankruptcy procedure for consumers, but also is the de facto bankruptcy procedure for small firms. When firms are non-corporate, debts of the firm are personal liabilities of the entrepreneur/owner. If the firm fails, entrepreneurs have an incentive to file for personal bankruptcy under the procedure known as Chapter 7, because both their business and personal debts will be discharged. Entrepreneurs filing under Chapter 7 must give up all assets they own in excess of an exemption level, but all of their future earnings are exempt from the obligation to repay--this is known as the "fresh start" in bankruptcy. Bankruptcy exemption levels are set by the states and they vary widely. Higher exemption levels make it more attractive for potential entrepreneurs who are risk averse to go into business, because more of their assets are sheltered from creditors if the firm fails. The fact that $20 \%$ of personal bankruptcy filings list business debts suggests how important personal bankruptcy procedures are for entrepreneurs (Sullivan et al, 1989).

In this paper we examine whether individuals are more likely to become entrepreneurs if they live in states with higher bankruptcy exemptions. There is a large literature explaining whether workers choose self-employment versus working for others and, in this paper, we test whether the bankruptcy system is a important part of the decision. We first develop a model of how variations in exemption levels affect incentives to own, start and end small businesses. We show that higher exemption levels provide partial wealth insurance, which makes potential entrepreneurs who are risk averse more likely to choose self-employment. However the relationship can turn negative if exemption levels are sufficiently high. We test the model empirically and find that families are more likely to own and start businesses if they live in states with higher bankruptcy exemption levels.

\footnotetext{
${ }^{1}$ We are grateful for comments from Mitchell Berlin, Charlie Brown, David de Meza, Alan Schwartz, and participants at seminars at Berkeley, Columbia, Michigan, Tilburg, the Philadelphia Fed, the Bank of England, the ALEA Annual Conference, and the NBER Summer Institute in Law and Economics. The N.S.F. provided financial support under grant number NSF-SBR-9617712.
} 
Section 1 of the paper discusses bankruptcy law, section 2 reviews the prior literature, section 3 contains the model and, in section 4 , we discuss our data and empirical results. Section 5 concludes and discusses policy implications.

\section{Bankruptcy Law}

The U.S. Constitution reserves for the Federal government the power to make laws concerning bankruptcy, so that bankruptcy law is uniform across the U.S. However in the Bankruptcy Code of 1978, Congress adopted a uniform set of bankruptcy exemptions but gave the states the right to opt out and set their own exemption levels. As a result, exemption levels are the only aspect of bankruptcy law that varies across states.

There are two different personal bankruptcy procedures - known as Chapters 7 and 13--and debtors are allowed to choose between them. As noted above, Chapter 7 requires debtors to give up all of their assets above their state's exemption level, but debtors' future earnings are completely exempt. All unsecured debts are discharged. Under the second personal bankruptcy procedure, Chapter 13, debtors are not obliged to give up any of their assets, but instead they must propose a multi-year plan to repay part of their unsecured debts from future earnings. If they fulfill the repayment plan, then the unpaid portion of the debt is discharged. For debtors in general, filing under Chapter 7 is more favorable because they often have no non-exempt assets. (About 70\% of all bankruptcy filings occur under Chapter 7.) For entrepreneurs, filing under Chapter 7 is particularly favorable, because they usually have large debts from their failed businesses and both their business and personal debts will be discharged under Chapter 7. If they instead filed under Chapter 13, the obligation to use part of their future earnings to repay debt would severely hamper their ability to obtain credit and start new businesses. From creditors' viewpoint, there is little difference between Chapters 7 and 13, since creditors are entitled to receive under Chapter 13 only the amount they would receive if the debtor filed under Chapter 7. We therefore model incentives to file for bankruptcy generally as a decision to file under Chapter $7 .^{2}$

\footnotetext{
${ }^{2}$ There are other differences between the two Chapters, which we ignore. For example, debts incurred by fraud are only dischargeable under Chapter 13. See White (1998) for discussion of personal bankruptcy law and additional references.
} 


\section{Prior Literature}

There is a large literature, both theoretical and empirical, on individuals' choice whether to become entrepreneurs. On the theoretical side, the two themes are risk aversion and credit constraints. In Kihlstrom and Laffont (1979), individuals have varying degrees of risk aversion, so that more risk-averse individuals become workers and less risk-averse individuals start firms. In Evans and Jovanovich (1989), individuals are risk-neutral, but they vary by both entrepreneurial ability and wealth. Individuals choose to become entrepreneurs if they have high entrepreneurial ability and choose to become workers otherwise. But because of credit constraints, the return to being an entrepreneur depends on individuals' initial wealth. Those who have high entrepreneurial ability but low wealth may be constrained in their ability to borrow, which reduces their return as entrepreneurs.

The empirical research on entrepreneurial behavior includes a number of studies that test for the importance of credit constraints. Evans and Jovanovic (1989) find that initial wealth is an important determinant of entrepreneurial success, supporting the hypothesis that entrepreneurs whose initial wealth is low are constrained in their ability to borrow. Holtz-Eakin, Joulfaian, and Rosen (1994) test for the importance of credit constraints by examining a sample of individuals who received inheritances. They find that entrepreneurs who receive inheritances are both more likely to remain in business, and, contingent on remaining in business, their revenues increase. They interpret their results as providing evidence that entrepreneurs are credit constrained and that receiving an inheritance loosens the constraint. Other research examines the conditions under which small firms are credit constrained. Petersen and Rajan (1994) show that the length and strength of the relationship between small firms and their lenders are important in determining whether small firms obtain loans. Berkowitz and White (2002) show that small firms are more likely to be turned down for loans if they are located in states that have higher bankruptcy exemptions.

Another strand of research has focused on factors besides credit constraints that affect the decision to become an entrepreneur. Important factors include differences in the tax treatment of income earned while working for others versus income from self- 
employment and potential entrepreneurs' race, ethnicity, immigrant status, and work history. See Bruce (2000), Schuetze (2000), Gentry and Hubbard (2000), Cullen and Gordon (2002), Borjas (1986), Fairlie and Meyer (1994), Evans and Leighton (1989), Fairlie (1999), Dunn and Holtz-Eakin (2000) and Hamilton (2000).

\section{Theory}

Suppose an individual or family is considering starting a business. Assume that the business would be non-corporate and, therefore, its debts would be legal obligations of the owner. (We consider incentives to start a corporate firm below.) Individuals or family members who do not start businesses are assumed to work for others. In this section we consider how personal bankruptcy law affects incentives to start businesses. We also consider how bankruptcy law affects lenders' incentives to shut down existing businesses. Because the model is intended for empirical testing, it is intentionally kept simple. ${ }^{3}$

\section{A. The decision to become an entrepreneur}

Suppose starting a business requires investing in a project that has a cost of $I$ in period 1 and an uncertain return of $R$ in period 2. In period 1, the potential entrepreneur has a fixed amount of wealth $W$ and a fixed amount of debt $B>0$. The $\operatorname{debt} B$ is unsecured, has an interest rate of $r$, and is due in period 2. It may have been incurred in period 1 or earlier and it may be used either to finance the project or for consumption. If potential entrepreneurs decide to start firms, their wealth in period 2 will be $W-I+B+R$, which varies because $R$ is uncertain. Suppose $\Omega=W-I+B+R$ and suppose the density of $\Omega$ is $f(\Omega)$.

In period 2, entrepreneurs owe $B(1+r)$ and may file for bankruptcy under Chapter 7. Suppose the bankruptcy exemption in the entrepreneur's state of residence is $X$, where $X$ can range from zero to unlimited (for homestead equity). Suppose the out-of-pocket cost

\footnotetext{
${ }^{3}$ In particular, the model ignores moral hazard, but the effects of moral hazard on the decision to become an entrepreneur are captured in the empirical estimates below. See Wang and White (2000) and Adler, Polak and Schwartz (1999) for models that consider moral hazard in the bankruptcy context.
} 
of filing for bankruptcy is $C{ }^{4}$ If entrepreneurs file for bankruptcy, then the debt of $B(1+r)$ will be discharged, but they must give up any wealth they own that exceeds the exemption level, or $\max [\Omega-C-X, 0]$. These funds are used for repayment to lenders. Suppose $\bar{\Omega}$ denotes the level of period 2 wealth at which entrepreneurs are indifferent between filing versus not filing for bankruptcy. Entrepreneurs' wealth is $\Omega-B(1+r)$ if they do not file for bankruptcy and $X$ if they do (assuming that they pay the cost of bankruptcy $C$ before filing). Therefore they are indifferent between filing versus not filing at the wealth level $\bar{\Omega}=X+B(1+r)$. They file for bankruptcy if $\Omega \leq \bar{\Omega}$ and do not file if $\Omega>\bar{\Omega}$. Their net wealth in period 2 after repaying the loan in full or filing for bankruptcy will be $\Omega-C$ if $\Omega \leq X+C, X$ if $X+C<\Omega \leq \bar{\Omega}$ and $\Omega-B(1+r)$ if $\Omega>\bar{\Omega}$.

The combination of borrowing and bankruptcy provides partial wealth insurance to potential entrepreneurs and therefore encourages them to go into business. When period 2 gross wealth $\Omega$ is higher than $X+B(1+r)$, entrepreneurs avoid bankruptcy and repay the debt in full. Therefore borrowing causes net wealth to fall by the amount $B(1+r)$. When gross wealth is below $X+B(1+r)$, entrepreneurs file for bankruptcy and repay either part of the loan or nothing. Therefore borrowing and bankruptcy cause net wealth to fall by a smaller amount than $B(1+r)$. The overall effect is that wealth is transferred from high wealth to low wealth states, which reduces the risk of going into business. If either the exemption level or the amount borrowed rose, then the level of partial wealth insurance would increase.

Now consider lenders' behavior. Suppose there are many potential entrepreneurs who are identical as of period 1 and they all apply to borrow from business lenders. Business

\footnotetext{
${ }^{4}$ This ignores the cost of bankruptcy stigma/reduced access to credit in the future. For entrepreneurs, the cost of bankruptcy stigma is probably small, since they are expected to take risks and to file for bankruptcy if their projects fail.

${ }^{5}$ An important question is whether potential entrepreneurs would be familiar with bankruptcy law and bankruptcy exemptions. One source of information is small business self-help manuals, such as Steingold (1999). These contain a clear explanation of bankruptcy. However even if entrepreneurs do not know the specifics of bankruptcy law, they probably know whether filing for bankruptcy in their states is favorable or not. This is because personal bankruptcy filing rates are very high —on average over the entire U.S., nearly $1.5 \%$ of households file for bankruptcy every year. Thus potential entrepreneurs are likely to know someone personally who has filed for bankruptcy.
} 
lenders are assumed to be risk neutral. They are willing to lend if they expect to make zero profits. Lenders' zero profit condition is:

$$
\int_{X+C}^{\bar{\Omega}}(\Omega-X-C) f(\Omega) d \Omega+\int_{\Omega}^{\infty} B(1+r) f(\Omega) d \Omega=B\left(1+r_{f}\right)
$$

where the first term on the left represents partial repayment by debtors in bankruptcy and $r_{f}$ is lenders' fixed opportunity cost of funds. Lenders set the interest rate $r$ so as to satisfy equation (1). If no interest rate satisfies (1), then they do not lend at all.

Changes in the exemption level $X$ affect both the interest rate and whether credit rationing occurs. As $X$ rises, the interest rate $r$ that satisfies eq. (1) rises at an increasing rate. This is because, at higher levels of $X$, borrowers are more likely to file for bankruptcy and therefore less likely to repay their loans. Lenders respond by raising the interest rate. But raising the interest rate becomes increasingly less effective as $X$ continues to rise, because borrowers are more likely to file for bankruptcy and therefore less likely to pay the higher rate. To illustrate, suppose $f(\Omega)$ is distributed normally with a mean of 2 and a standard deviation of .25 and suppose that $B=1, C=0$ and $r_{f}=0.1$. Then if $X$ exceeds .9 (more than $90 \%$ of the loan amount), no interest rate is high enough to satisfy the zero profit constraint and lenders cease lending completely. Thus credit rationing takes a very simple form: lenders lend to all potential entrepreneurs if $X \leq .9$ and do not lend at all if $X>.9 .^{6}$

Now suppose potential entrepreneurs decide to work for others rather than starting businesses. Their period 2 wealth is assumed to be the certain amount $W^{\prime}$. They may or may not borrow in period 1, but we assume that if they borrow, they repay in full and do not file for bankruptcy in period 2 .

\footnotetext{
${ }^{6}$ Longhofer (1997) shows that if borrowers differ in their degree of credit-worthiness along a dimension that lenders can observe, then lenders gradually impose credit rationing on more credit-worthy borrowers as the exemption level rises. Note that this form of credit rationing differs from that in the Stiglitz and Weiss (1981) model and other credit models involving asymmetric information. In Stiglitz-Weiss, there is excess demand for loans at the prevailing interest rate, but lenders do not raise the interest rate. This is because borrowers differ in the riskiness of their projects, but lenders cannot observe risk levels. As a result, raising the interest rate would cause adverse selection in the borrower population, resulting in losses for lenders. So lenders instead ration loans by lending to randomly selected borrowers. See de Meza (2002) for a review of recent models of credit with asymmetric information and their implications for whether too much or too little lending occurs.
} 
Potential entrepreneurs' utility is assumed to depend on their net wealth and they are assumed to be risk averse. They choose to become entrepreneurs if their expected utility in period 2 when they start businesses exceeds their utility in period 2 when they work for others, or if:

$$
\int_{-\infty}^{X+C} U(\Omega-C) f(\Omega) d \Omega+\int_{X+C}^{\bar{\Omega}} U(X) f(\Omega) d \Omega+\int_{\bar{\Omega}}^{\infty} U(\Omega-B(1+r)) f(\Omega) d \Omega \geq U\left(W^{\prime}\right)
$$

Now consider how changes in the exemption level affect entrepreneurs' expected utility. Solving for $d r / d X$ from (1) and for $d E U / d X$ from the left hand side of (2) and substituting, we get:

$$
\frac{d E U}{d X}=U^{\prime}(X) \int_{X+C}^{\bar{\Omega}} f(\Omega) d \Omega-\int_{\bar{\Omega}}^{\infty} U^{\prime}(\Omega-B(1+r)) f(\Omega) d \Omega \frac{\int_{X+C}^{\bar{\Omega}} f(\Omega) d \Omega+C f(\bar{\Omega})}{\int_{\bar{\Omega}}^{\infty} f(\Omega) d \Omega-C f(\bar{\Omega})}
$$

Consider the special case of (3) when the interest rate is fixed, so that $d r / d X=0$. This might be the case, for example, if entrepreneurs borrow from relatives to finance their businesses and the relatives do not set the interest to reflect risk. ${ }^{7}$ Since $d r / d X$ is the fraction on the right hand side of (3), the value of $d E U / d X$ in this case becomes $U^{\prime}(X) \int_{X+C}^{\bar{\Omega}} f(\Omega) d \Omega$, which must be positive. Thus when interest rates are fixed and credit is available, increases in the exemption level unambiguously raise the attractiveness of owning a business. Also, individuals' fixed utility level from working for others, $U\left(W^{\prime}\right)$, does not depend on $X$. Therefore when loans are available at fixed interest rates, an increase in the exemption level always increases the attractiveness of going into business relative to working for others.

Now consider a second special case when the interest rate is endogenous, but the cost of bankruptcy $C$ is zero. Then the sign of $d E U / d X$ in (3) becomes the sign of: 


$$
U^{\prime}(X)-\frac{\int_{\Omega}^{\infty} U^{\prime}(\Omega-B(1+r)) f(\Omega) d \Omega}{\int_{\Omega}^{\infty} f(\Omega) d \Omega}
$$

This expression equals entrepreneurs' marginal utility of wealth when they file for bankruptcy and keep $X$ minus their average marginal utility of wealth when they avoid bankruptcy and keep $\Omega-B(1+r)$. For risk averse entrepreneurs, expression (4) must be positive, since their wealth when they file for bankruptcy is lower than their wealth when they avoid bankruptcy, so their marginal utility of wealth must be higher when they file for bankruptcy. Thus when $C=0$, increases in the exemption level unambiguously raise the expected utility of becoming an entrepreneur, as long as credit is available and potential entrepreneurs are risk averse. This is because entrepreneurs pay a fair price via the interest rate for the partial wealth insurance that bankruptcy provides. Because riskaverse entrepreneurs always wish to purchase additional insurance when it is sold at a fair price, having a higher exemption level must make them better off.

Finally, suppose $C$ is positive. In this case the sign of (3) is ambiguous, since the second term in (3) becomes increasingly negative as $C$ becomes larger. Thus for any given exemption level, $d E U / d X$ must be positive if $C=0$, but it gets smaller and may turn negative as $C$ rises. This means that if $C$ is large enough, risk-averse entrepreneurs may prefer a lower rather than higher exemption level, i.e., less insurance. The intuition here is that when $C$ is positive, entrepreneurs pay more than the fair price for the insurance that bankruptcy provides--they pay the fair price in the form of higher interest rates, but they also must pay bankruptcy costs. As the exemption level increases, entrepreneurs' probability of filing for bankruptcy rises, which raises expected bankruptcy costs, and this extra cost rises more quickly when $C$ is higher. This means that if $C$ is high, entrepreneurs rarely find it worthwhile to file for bankruptcy. As a result, even risk averse entrepreneurs may prefer a lower rather than higher exemption

\footnotetext{
${ }^{7}$ Other types of loans in which the interest rate is fixed include borrowing that occurred independently of the investment project and business borrowing that is involuntary on the lender's part (such as unpaid rent or wages or tort judgments against the firm).
} 
level, because when the cost of filing for bankruptcy is very high, a high exemption level makes it unattractive to become an entrepreneur. ${ }^{8}$

The overall results are that, when bankruptcy costs are zero, increases in the exemption level always increase the attractiveness of becoming an entrepreneur as long as loans are available. But as bankruptcy costs rise, increases in the exemption level may decrease rather than increase the attractiveness of becoming an entrepreneur.

\section{B. The decision to shut down a business}

Now consider how changes in the exemption level affect whether businesses in financial distress shut down. For most small businesses, the timing of shutdown is determined by when creditors foreclose on equipment that is essential to the firms' operations (see LoPucki, 1983, for discussion).

Assume that a failing firm's creditor has a choice between shutting the firm down in period 2 versus allowing it to continue to operate until period 3. Because of the firm's poor financial condition, we assume that the entrepreneur cannot obtain new loans from either new or old creditors. If the firm continues to operate for an additional period, then the entrepreneur's gross wealth in period 3 is denoted $Z$, which has the distribution $g(Z) .{ }^{9}$ The firm's debt at the end of period 2 is assumed to be $B$ ', which exceeds $B$ because of accrued interest and default charges. In period 3, the firm therefore owes $B^{\prime}(1+r)$. Because the loan is in default, the interest rate $r$ remains the same. The creditor's expected return if the firm continues to operate until period 3 is:

$$
\int_{X+C}^{\bar{Z}}(Z-C-X) g(Z) d Z+\int_{\bar{Z}}^{\infty} B^{\prime}(1+r) g(Z) d Z
$$

where $\bar{Z}=X+B^{\prime}(1+r)$ denotes the level of gross wealth in period 3 at which the entrepreneur is indifferent between filing versus not filing for bankruptcy.

\footnotetext{
${ }^{8}$ As an example, suppose the utility function is $U=\left(\right.$ Net Wealth) ${ }^{\alpha}$ and $C=.1$ (or one-tenth of the loan amount). Also suppose potential entrepreneurs are very risk averse, or $\alpha=.2$. Then entrepreneurs' expected utility is maximized at an exemption level of $X=.35$. This means that potential entrepreneurs are more likely to start businesses as $X$ increases if $X<.35$, but less likely to start businesses as $X$ increases if $X>$.35. If entrepreneurs were less risk averse (i.e., had levels of $\alpha$ closer to one), then the optimal exemption level would be lower.

${ }^{9} Z$ includes both personal and business assets of the entrepreneur. Entrepreneurs can protect assets from creditors by, for example, using business assets to pay off part of their mortgages, assuming that additional home equity is exempt.
} 
Differentiating (5) with respect to the exemption level, we find that the creditor's expected return is negatively related to the exemption level, meaning that allowing failing firms to continue operating is less worthwhile in states that have high exemption levels.

The alternative for creditors is to shut the firm down in period 2. We assume that when creditors shut a failing firm down, entrepreneurs file for bankruptcy. In this case, entrepreneurs' wealth is assumed to be less than $\bar{\Omega}$ and therefore, using eq. (1), creditors must receive either zero or $\Omega-X-C$. Since creditors would not bother to shut down a firm if they expected to receive nothing, suppose their expected return is $\Omega-X-C$. This expression is also negatively related to the exemption level.

Thus the model suggests that higher bankruptcy exemptions reduce creditors' expected return from failing firms, regardless of whether creditors shut these firms down or allow them to continue operating.

\section{Summary}

We have shown the following: (1) The bankruptcy system makes going into business more attractive to potential entrepreneurs by providing them with partial wealth insurance. (2) If the interest rate on business loans is fixed or if the cost of filing for bankruptcy is zero, then becoming an entrepreneur is always more attractive as the exemption level rises. If the interest rate on loans is endogenously determined and the cost of filing for bankruptcy is positive, then increases in the exemption level may lower the attractiveness of owning a business at higher exemption levels. (3) Bankruptcy exemption levels do not have a clear effect on whether creditors have an incentive to shut down existing firms that are in financial distress or allow them to continue operating.

\section{Empirical Tests}

Our empirical work explains whether families own, start or end businesses as a function of the bankruptcy exemption in the state where the family lives and other variables. We use family-level panel data from two different Survey of Income and Program Participation (SIPP) panels. The first panel consists of families who were interviewed in 1993, 1994, and 1995 and the second consists of families who were interviewed in 1996, 1997, and 1998. Each panel contains about 20,000 families. Our dataset combines the two panels, so that it covers the period 1993 through 1998. Because 
different questions about self-employment were asked in the two panels, we categorize families as self-employed in 1993-95 if anyone in the family owned a business and did not work at a job, while we categorize families as self-employed during 1996-981 if one or more family members owned businesses. The sample size is about $98,000{ }^{10}$

An important issue is whether bankruptcy exemption levels can be treated as exogenous to the self-employment decision. As discussed above, the 1978 Bankruptcy Code specified a uniform Federal bankruptcy exemption, but allowed states to opt out by adopting their own exemptions. The Code went into effect in late 1979 and all states adopted their own bankruptcy exemptions within a couple of years thereafter, although about one-third of the states allowed their residents to choose between the state's exemption and the Federal exemption. Since 1982, the pattern has been that only a few states change their exemption levels each year, mainly to correct nominal exemption levels for inflation. ${ }^{11}$ Because most states adopted their bankruptcy exemptions within a short period after the Code went into effect, we treat exemption levels as exogenous to self-employment decisions. ${ }^{12}$

States have separate bankruptcy exemptions for various types of property, but the largest and most variable is the exemption for equity in owner-occupied housing---the "homestead" exemption. ${ }^{13}$ Homestead exemptions range from zero (in Maryland and Delaware) to unlimited (in Texas, Florida, Minnesota, Oklahoma, Kansas, Arkansas, Iowa and S. Dakota). High homestead exemptions reduce the risk of owning a business because, if the business fails, entrepreneurs are less likely to lose their homes. In addition, homestead exemptions protect non-housing assets, because entrepreneurs can convert non-housing assets into home equity by using the assets to pay down their

\footnotetext{
${ }^{10}$ In each SIPP panel, families are questioned every four months. Because bankruptcy exemption data is reported annually, we treat the SIPP data as annual by using only the $1^{\text {st }}, 4^{\text {th }}$, and $7^{\text {th }}$ waves. We include only families that responded to all three of the relevant waves. Variables that are reported at the household or individual level are converted to the family level. The SIPP is available from www.bls.census.gov/sipp.

${ }^{11}$ The Federal homestead exemption remained the same from 1978 to 1994 , when it was doubled from $\$ 7,500$ to $\$ 15,000$. Our data on exemption levels is taken from Elias et al (1994 and other editions). See Lin and White (2001) for a list of exemption levels and changes by state from 1993 to 1997.

${ }^{12}$ Another reason for treating exemption levels as exogenous to the self-employment decision is that the volume of consumer loans is much larger than that of small business loans. Thus whether states raise, lower or leave their exemption levels unchanged depends mainly on the relative lobbying strength of credit card banks versus consumer representatives.

${ }^{13}$ Most states also have exemptions for household belongings, equity in vehicles, retirement accounts, and a wildcard category that can be applied to any type of asset, but they are almost always small.
} 
mortgages, as long as their home equity remains below the homestead exemption. We therefore use the homestead exemption as our bankruptcy exemption variable. ${ }^{14}$

Most states allow married couples to take larger homestead exemptions if they file for bankruptcy jointly. We therefore adjust the exemption level if the family head is married and lives in a state that allows married couples to claim a larger exemption. In states that allow bankruptcy filers to choose between the state and the Federal exemptions, we use the Federal homestead exemption if it is larger.

We construct a distribution of homestead exemption levels over all combinations of state and marital status and divide the portion of the distribution where exemption levels are not unlimited into quartiles. ${ }^{15}$ We then create a series of dummy variables representing each quartile of the distribution above the lowest, plus an additional dummy variable for states that have unlimited homestead exemptions. States with unlimited homestead exemptions are coded as having the highest "limited" exemption level, so that the coefficient of the unlimited exemption dummy captures the effect of the exemption being unlimited rather than high. We use the quartile specification to represent the distribution of exemption levels, because the relationship between exemption levels and self-employment is predicted to be positive at low exemption levels, but could be negative at high exemption levels. This specification of the relationship is not at all restrictive.

Finally, filing for bankruptcy is less beneficial for renters than for homeowners, because renters who file for bankruptcy cannot make use of the homestead exemption. To take account of this difference, we interact each of the exemption categories with whether families own or rent their homes. This means that there are ten separate exemption categories, of which we omit the lowest exemption category for renters. ${ }^{16}$

Now consider other variables. The SIPP asks separate questions concerning how much families earn from working for others versus from self-employment. Because

\footnotetext{
${ }^{14}$ See White (1998) for discussion of other strategies to convert assets from non-exempt to exempt.

${ }^{15}$ For 1993 , the lowest quartile includes homestead exemptions up to $\$ 5,000$, the $2^{\text {nd }}$ quartile includes the range from above $\$ 5,000$ to $\$ 10,000$, the $3^{\text {rd }}$ includes exemptions from above $\$ 10,000$ to $\$ 50,000$, and the $4^{\text {th }}$ quartile includes exemptions from above $\$ 50,000$ to the maximum dollar level.

${ }^{16}$ Although we ignored moral hazard in the theoretical section, the estimated coefficients of the exemption dummies capture the marginal effect of moral hazard on the decision to be self-employed. For example, suppose non-exempt assets can be more easily hidden when filing for bankruptcy in high exemption states
} 
families whose workers are partly or fully self-employed spend less time working for others, we first estimate an OLS model that explains the log of earnings for families that do not have self-employment earnings. The explanatory variables are the head's education level, the head's age, and demographic variables. We use the results of this model to predict the log of earnings from working for others for those families that have self-employment earnings. The predicted values are an estimate of the amount that families with self-employment would earn if all of their workers spent all of their time working for others, or the opportunity cost of being self-employed. The combined distribution of predicted log earnings for families with self-employment and actual log earnings for families without self-employment is divided into quartiles and we construct dummy variables for each quartile, omitting the lowest. ${ }^{17}$

We also have data on income from wealth, retirement income, and income from transfers. We divide the distribution of income from wealth into four categories, of which the lowest category consists of non-positive values and the three highest categories each contain the same number of families. We exclude the non-positive values and enter separate dummy variables for each category of positive values (the latter are referred to as quartiles of the income from wealth distribution). We follow the same procedure for retirement income and income from transfers.

We also enter a vector of demographic variables as additional controls: the number of earners in the family, the head's education level in years, the age of the head in decades (under thirty is the excluded category and each variable represents the marginal effect of being one decade older), and dummy variables for the number of persons in the family (one person families are excluded), for whether the head is married, whether the head is a single female, whether the head is African-American, Mexican, other Spanish, or Eastern European, and whether the family lives in a metropolitan area. Additional variables capture local macroeconomic conditions and other state-level policy variables that might

than in low exemption states. Then the estimated coefficient of the fourth quartile and unlimited exemption variables will be higher because moral hazard makes self-employment more attractive in these states.

${ }^{17}$ This procedure ignores the possibility of selection bias in predicting what families that are self-employed would earn if some of their members instead worked for others. Selection bias will not be a problem if characteristics that cause families to be more successful in working for others also make them more successful as entrepreneurs. However, Bruce (2000) presents evidence for heads of households that the returns to both education and age are greater for those who are self-employed. Whether the same pattern 
affect the decision to be self-employed. These include the state unemployment rate, the fraction of the labor force that is employed in the non-farm sector, the rate of growth of output in the state over the past year, and the maximum state personal income tax rate. We enter the non-farm employment rate as a correction for the fraction of state economic activity that is due to farming, since bankruptcy law is different for farmers. The maximum state income tax rate is relevant for two reasons. First, opportunities for tax evasion are greater for the self-employed and the ability to evade taxes is more valuable when rates are higher. Second, income taxes-like bankruptcy--provide partial wealth insurance and the degree of insurance rises with the tax rate. Both of these factors suggest that becoming an entrepreneur is more attractive in states with higher maximum tax rates, although the positive effect of taxes on the probability of being self-employed is reduced because full loss offset is not allowed. ${ }^{18}$ Finally, we enter year effects and a dummy variable that differentiates between the two SIPP panels (results not reported). ${ }^{19}$

Summary statistics are given in table A1. The probability of owning a business is .11. Note that businesses in the sample tend to be small: mean business income is $\$ 2,400$ per month. $^{20}$

\section{A. The decision to own a business}

Our benchmark case is a random effects probit model that explains whether families own businesses. The results are given in columns (1) and (2) of table 1 (robust standard errors clustered by families are shown). They show that all of the exemption variables are positive and statistically significant for homeowners and the unlimited exemption variable is positive and statistically significant for renters. The third quartile, fourth quartile and unlimited exemption variables for homeowners are significantly different from the lowest quartile exemption variable for homeowners $(p=.0199, .0078$, and .0000 , respectively). Table 2 , column (1), shows the predicted probabilities of owning a

would hold for families is unclear. This suggests that it would be useful in future research to incorporate a selection correction in the procedure for estimating the opportunity cost of being self-employed.

${ }^{18}$ Bruce (2000), Gentry and Hubbard (2000), and Cullen and Gordon (2002) discuss and test more detailed specifications of the effect of taxes on self-employment, including a measure of the difference in marginal tax rates when individuals are self-employed versus working for others and a measure of tax progressivity. State maximum tax rates are taken from Moody (1999) and earlier years of the same publication.

${ }^{19}$ Our specification is similar to that of Gentry and Hubbard (2000), Bruce (2000) and Schuetze (2000), but we use families rather than household heads as the unit of analysis.

${ }^{20}$ All calculations use weights that make the sample representative of U.S. families. 
business at varying exemption levels. ${ }^{21}$ (Asterisks indicate probabilities that are significantly different from the lowest quartile level for homeowners or renters, whichever is relevant.) For homeowners, the probability of owning a business increases from .10 when the homestead exemption is in the lowest two quartiles to .11 when the exemption is in the highest two quartiles and jumps to .135 when the exemption is unlimited. The relationship between the exemption level and homeowners' probability of owning businesses is monotonically increasing, rather than rising at low exemption levels and then falling. The increase in the probability of owning a business from the lowest to the unlimited exemption level is about $35 \%$. For renters, the probability of owning a business generally rises as the exemption level increases, but the pattern is not monotonic. The probability of owning a business rises from .083 at the lowest exemption level to .107 when the exemption is unlimited, or by $29 \%$. These results imply that both homeowners and renters respond strongly to increases in the homestead exemption in making their decisions to become self-employed. For renters, this presumably reflects the fact that many of them expect to become homeowners in the future. The fact that self-employment for owners is monotonically related to the exemption level suggests that many entrepreneurs' loans are not priced to accurately reflect risk.

The results for other variables are generally similar to those found in the previous work. Like Schuetz (2000), we find that families are more likely to be self-employed when the unemployment rate is higher and, like Bruce (2000) and Schuetz (2000), we find that families are more likely to be self-employed when the maximum state tax rate is higher. We also find that having more earners significantly increases the probability that families own businesses. This is presumably because families that have other earners are less discouraged by the high variance of self-employment earnings. ${ }^{22}$

\section{B. The decision to own a "big" business.}

Because the average business in our dataset is small, we reran the benchmark case, but changed the dependent variable so that families are classified as self-employed only if

\footnotetext{
${ }^{21}$ We predict the probability of being self-employed separately for each family, using the family's actual characteristics and the specified exemption level. We then take a weighted average of the predictions.

${ }^{22}$ As a robustness check, we reran the benchmark model using individuals rather than families as the unit of observation. The results in general were very similar and the significance and magnitude of the exemption variables remained essentially the same.
} 
their business income was greater than $\$ 2,000$ per month. ${ }^{23}$ The results are shown in table 1, columns (3) and (4). Among the exemption variables, only the unlimited exemption variable for owners is significantly different from the lowest quartile exemption variable for owners $(p<.0000)$. The predictions are shown in table 2 , column (2). The predicted probability of owning a business for homeowners rises from .047 in the lowest quartile of the exemption distribution to .060 when the exemption is unlimited, or by about $28 \%$. For renters, the unlimited exemption variable is also positive and it is significant at the $10 \%$ level. The probability of renters owning big businesses rises from about .035 in the lowest quartile of the exemption distribution to .045 in states with unlimited exemptions, or $29 \%$. Thus owners of large and small businesses respond similarly to variations in exemption levels.

\section{Choice of organizational form.}

We also examined whether bankruptcy law affects individuals' decisions to organize their businesses in corporate versus non-corporate form. As discussed above, higher bankruptcy exemption levels make it more attractive to own a non-corporate business relative to working for others. In contrast when businesses are corporate, owners' assets and debts are legally distinct from the assets and debts of their corporations, so that owners are not liable for the losses of their corporations. Strictly speaking, this means that whether the bankruptcy exemption level is high or low should have no effect on how favorable it is to own a corporate business relative to working for others. However, in practice business lenders often require that owners personally guarantee loans to their small corporate businesses and these guarantees muddy the distinction between corporate versus non-corporate businesses. ${ }^{24}$ As a result, families may find it more attractive to own both corporate and non-corporate businesses in states with higher personal bankruptcy exemption levels. ${ }^{25}$

The SIPP asks families if their businesses are non-corporate or corporate. We ran a weighted multinomial logit model explaining whether families own corporate businesses,

\footnotetext{
${ }^{23}$ The average monthly income of "big" businesses is $\$ 5,700$.

${ }^{24}$ Berkowitz and White (2002) found that business lenders ignore organizational form when deciding whether to offer loans to small businesses.

${ }^{25}$ Most small firms have a tax incentive to choose non-corporate status, since firms often make losses and these losses can be deducted against other income of the entrepreneur or spouse.
} 
non-corporate businesses, or no business. ${ }^{26}$ The results (not shown) indicate that the exemption variables are strongly statistically significant in the decision by homeowners whether to own non-corporate businesses, but are less statistically significant in the decision by homeowners to own corporate businesses or the decision by renters to own either type of business. The predicted probabilities of owning corporate and noncorporate businesses are shown in table 2, columns (3) and (4). Homeowners' probability of owning non-corporate businesses rises from about .08 in the lower half of the exemption distribution to .11 when the exemption level is unlimited, or by about $38 \%$. Homeowners' probability of owning corporate businesses rises from about .026 in the lower half of the exemption distribution to .029 when the exemption is unlimited, or by about $14 \%$. Renters' probability of owning non-corporate businesses rises from about .053 in the lowest quartile of the exemption distribution to 083 , or by $56 \%$, when the exemption is unlimited, but renters' probability of owning corporate businesses is not significantly related to the exemption variables. Thus exemption levels have an important effect on whether both groups own non-corporate businesses, but they affect only homeowners' decisions to own corporate businesses.

\section{The decision to start a business}

Now turn to families' decisions to start businesses. Define a dummy variable for starting a business that equals one if a family did not own a business in 1993, 1994, 1996, or 1997, but owned a business in the following year. Because a new SIPP panel starts in 1996, we have no information on business starts between 1995 and 1996. The explanatory variables are the same as those used previously. Explanatory variables for 1993 are used to explain whether families started businesses between 1993 and 1994 and similarly for later years. The sample consists of families in both SIPP panels that did not own businesses in the earlier year. Because we lose two years of data and also lose observations of families that owned businesses in the earlier year, the sample size falls to 58,000 .

In table 3, columns (1) and (2), we report the results of a random effects probit model explaining whether families start businesses. For homeowners, all of the exemption variables have positive signs, but only the unlimited exemption variable is significantly

\footnotetext{
${ }^{26}$ If families own more than one business, we use the organizational type of the first business reported.
} 
different from the lowest quartile variable for homeowners and then the $p$ value is only .08 . For renters, the $4^{\text {th }}$ quartile exemption variable is positive and significantly different from the lowest quartile variable for renters $(p=.005)$. The predicted probabilities are shown in table 4, column (1). Homeowners' probability of starting businesses rises from .023 in the lowest quartile of the exemption distribution to .028 in unlimited exemption states, or by $22 \%$. For renters, the pattern of the exemption variables is non-monotonic, but the probability of owning a business rises from .019 in the lowest quartile to .027 in the highest quartile, or by $40 \%$. These results suggest that bankruptcy exemption levels affect both owners' and renters' decisions to start businesses.

Among the other variables, the only significantly positive factor in families' decisions to start businesses is the head having more years of education. Significantly negative factors include having a single female head, having a head who is over 60, having a Mexican or African-American head, or having higher earnings from working at a job. None of the state level macroeconomic variables or the maximum tax rate variable is statistically significant.

\section{E. The decision to end a business}

Now turn to the question of whether exemption levels affect the businesses' probability of shutting down. Define a dummy variable for ending a business that equals one if a family owned a business in 1993, 1994, 1996, or 1997, but did not own a business in the following year. Again because a new SIPP panel started in 1996, we have no information on decisions to end businesses between 1995 and 1996. Explanatory variables for each year are used to explain whether families end businesses between that

year and the next. The sample includes only families that owned businesses in the earlier year, so that it falls to about 7,200. The specification otherwise remains the same.

A caveat is that while our theoretical model deals only with shutdowns of distressed businesses, in fact businesses shut down for other reasons--such as the entrepreneur retiring, moving away, selling out, or accepting a job working for others. Because these other reasons for shutting businesses are probably unaffected by bankruptcy law, they tend to bias the effect of the exemption variables downward.

The results are shown in table 3, columns (3) and (4). None of the exemption variables is significantly different from the lowest quartile value in the relevant group. 
The predicted probabilities of businesses shutting down are shown in table 4, column (2). Homeowners' probability of ending businesses rises fairly monotonically from about .141 in the lowest exemption states to .167 in states with unlimited exemptions, or by about $18 \%$. Renters' probability of ending businesses rises from .22 in the lowest exemption states to .244 in states with unlimited exemptions, although the increase is not monotonic. Thus the evidence suggests that high exemption levels are associated with higher rates of business closure, but additional research will be needed to determine if a significant relationship exists.

Among the other variables, families with high income from wealth are significantly less likely to close their businesses, which provides additional support for the hypothesis that wealth constraints are an important determinant of success in small business.

\section{Conclusion}

In this paper, we test whether potential entrepreneurs are more likely to own, start and end small businesses if they live in states with higher personal bankruptcy exemptions. Entrepreneurs benefit from higher personal bankruptcy exemptions because exemptions provide partial wealth insurance, although at the cost of a reduction in credit availability as the exemption level rises. Exemption levels are set by the states and they vary widely. We find that families who are homeowners are about $35 \%$ more likely to own businesses if they live in states with high or unlimited rather than low homestead exemptions, and the difference is statistically significant. Renters are $29 \%$ more likely to own businesses if they live in high exemption states and this difference is also statistically significant. Families' decisions to own non-corporate businesses are more responsive to changes in exemption levels than their decisions to own corporate businesses. Bankruptcy exemptions also affect the decision to start a business: homeowners are $28 \%$ more likely to start businesses if they live in states with unlimited rather than low homestead exemptions, although the relationship is only significant at the $8 \%$ level. However we did not find a significant relationship between exemption levels and whether families end their businesses.

Congress recently passed legislation to reform personal bankruptcy law, although currently the House and Senate are unable to agree on a compromise version. The most 
significant change would be that debtors who earn more than the median income level would be barred from filing under Chapter 7 and taking advantage of the "fresh start". Instead they would have to file under a new and harsher version of Chapter 13, which obliges debtors to use all of their future earnings beyond a not-very-generous Internal Revenue Service formula to repay pre-bankruptcy debt. The obligation to repay would continue for five years after the bankruptcy filing. These reforms are intended to reduce abuse of the bankruptcy system by well-off debtors. However our analysis suggests that an unintended consequence of these reforms would be a reduction in the attractiveness of self-employment. Instead of being able to shelter their future incomes and some or all of their assets from creditors if their businesses fail, owners of failed businesses would face heavy taxation of their future earnings to repay their old business debts. Owners of failed businesses would also be discouraged from taking high-paying jobs, because taking a job that pays more than the median income level would prevent them from filing for bankruptcy under the more-favorable Chapter 7. And lenders would be loath to lend to once-failed business owners who want to start new businesses, because owners have little incentive to work hard if additional earnings mainly benefit their old creditors. While some self-employment ventures under the current bankruptcy law are probably inefficient, the proposed changes in personal bankruptcy procedures make the small business environment so much tougher that both efficient and inefficient ventures are likely to be eliminated. The result could be a slower rate of growth for the U.S. economy. 


\section{References}

Adler, Barry, Ben Polak, and Alan Schwartz, "Regulating Consumer Bankruptcy: A Theoretical Inquiry.” J. of Legal Studies 29:2, part 1 (2000): 585-613.

Berkowitz, Jeremy, and Michelle J. White, "Bankruptcy and Small Firms' Access to Credit." NBER working paper 9010 (2002). Forthcoming, RAND Journal of Economics.

Borjas, George, "The Self-Employment Experience of Immigrants," J. of Human Resources, vol. 21 (1986): 485-506.

Bruce, Donald, "Effects of the United States Tax System on Transitions Into SelfEmployment," Labour Economics 7:5 (2000): 545-574.

Cavalluzzo, Ken, Linda Cavalluzzo, and John D. Wolken, "Competition, Small Business Financing and Discrimination: Evidence from a New Survey." Board of Governors of the Federal Reserve System, Finance and Economics Discussion Series 99/25 (1999).

Cullen, Julie B., and Roger H. Gordon (2002), “Taxes and Entrepreneurial Activity: Theory and Evidence for the U.S.” NBER working paper 9015.

De Meza, David, “Overlending?” Economic Journal 112 (2002), pp. F17-F31.

Dunn, Thomas, and Douglas Holtz-Eakin, 2000, "Financial Capital, Human Capital, and the Transition to Self Employment: Evidence from Intergenerational Links," J. of Labor Economics 18:2 (2000): 282-305.

Elias, S., A. Renauer, and R. Leonard, How to File for Bankruptcy, $4^{\text {th }}$ edition. Berkeley: Nolo Press, 1994.

Evans, David S., and Boyan Jovanovic, “An Estimated Model of Entrepreneurial Choice Under Liquidity constraints,” J. of Political Economy 97 (1989): 808-827.

Evans, David S., and Linda Leighton, "Some Empirical Aspects of Entrepreneurship," American Economic Review 79 (1989): 519-535.

Fairlie, Robert W., "The Absence of the African-American Owned Business: An Analysis of the Dynamics of Self-Employment," Journal of Labor Economics 17:1 (1999): 80-108.

Fairlie, Robert W., and Bruce Meyers, "The Ethnic and Racial Character of Self-Employment." National Bureau of Economic Research Working Paper Number 4791 (1994).

Gentry, William M., and R. Glenn Hubbard, "Tax Policy and Entrepreneurial Entry," American Economic Review 90:2 (2000): 282-287. 
Hamilton, Barton H., "Does Entrepreneurship Pay? An Empirical Analysis of the Returns to Self-Employment," J. of Pol.Econ., vol. 108 (2000): 604-31.

Holtz-Eakin, Douglas, David Joulfaian, and Harvey Rosen, "Sticking It Out:

Entrepreneurial Survival and Liquidity Constraints," J. of Political Economy 102 (1994): 53-75.

Kihlstrom, Richard, and Jean-Jacques Laffont, "A General Equilibrium Entrepreneurial Theory of Firm Formation Based on Risk Aversion," J. of Political Economy 87 (1979): 719-748.

Lin, Emily Y., and Michelle J. White, "Bankruptcy and the Market for Mortgage and Home Improvement Loans," Journal of Urban Economics 50:1 (2001): 138-162.

Longhofer, Stanley D., “Absolute Priority Rule Violations, Credit Rationing, and Efficiency,” J. of Financial Intermediation 6 (1997): 249-67.

LoPucki, Lynn M., "The Debtor in Full Control: Systems Failure under Chapter 11 of the Bankruptcy Code?" American Bankruptcy Law Journal 57, part I (1983): 99-126 and 57, part II (1983): 247-273.

Moody, Scott, editor, Facts and Figures on Government Finance. New York, Tax Foundation, $32^{\text {nd }}$ edition, 1999.

Petersen, Mitchell A., and R. G. Rajan, "The Benefits of Lending Relationships: Evidence from Small Business Data,” J. of Finance 49 (1994): 3-37.

Schuetze, Herb J., "Taxes, Economic Conditions and Recent Trends in Male SelfEmployment: A Canada-U.S. Comparison,” Labour Economics 7:5 (2000): 507-544.

Steingold, F.S., Legal Guide to Starting \& Running a Small Business, Vol. 1. Berkeley CA: Nolo Press, 1999.

Sullivan, T., E. Warren and J. Westbrook, As We Forgive Our Debtors. New York: Oxford University Press, 1989.

Stiglitz, J.E., and A. Weiss, "Credit Rationing in Markets with Imperfect Information," American Economic Review 71 (1981): 393-410.

Wang, Hung-jen, and Michelle J. White, “An Optimal Personal Bankruptcy System and Proposed Reforms," J. of Legal Studies XXXIX (2000): 255-286.

White, Michelle J., "Why it Pays to File for Bankruptcy: A Critical Look at Incentives under U.S. Bankruptcy Laws and A Proposal for Change," University of Chicago Law Review 65 (1998): 685-732. 
Table 1. Effects of Bankruptcy on Whether Families Own Businesses

\begin{tabular}{|c|c|c|c|c|}
\hline & \multicolumn{2}{|c|}{ Any business } & \multicolumn{2}{|c|}{ Big business } \\
\hline & (1) & (2) & (3) & (4) \\
\hline Explanatory Variables & Coef. & s.e. & Coef. & s.e. \\
\hline $1^{\text {st }}$ quartile - owner & 0.119 & 0.037 & 0.158 & 0.057 \\
\hline $2^{\text {nd }}$ quartile - renter & 0.0229 & 0.039 & 0.0940 & 0.063 \\
\hline $2^{\text {nd }}$ quartile - owner & 0.136 & 0.037 & 0.130 & 0.057 \\
\hline $3^{\text {rd }}$ quartile - renter & 0.0753 & 0.043 & 0.0096 & 0.066 \\
\hline $3^{\text {rd }}$ quartile - owner & 0.175 & 0.038 & 0.170 & 0.057 \\
\hline $4^{\text {th }}$ quartile - renter & 0.0235 & 0.050 & 0.0133 & 0.069 \\
\hline $4^{\text {th }}$ quartile - owner & 0.201 & 0.042 & 0.210 & 0.060 \\
\hline Unlimited - renter & 0.155 & 0.051 & 0.131 & 0.075 \\
\hline Unlimited - owner & 0.312 & 0.042 & 0.293 & 0.060 \\
\hline Number of earners & 0.359 & 0.011 & 0.106 & 0.013 \\
\hline Metropolitan area & -0.0690 & 0.019 & -0.0077 & 0.025 \\
\hline Education level & 0.0101 & 0.002 & 0.0159 & 0.003 \\
\hline Single female head & -0.409 & 0.034 & -0.583 & 0.047 \\
\hline Married head & -0.0302 & 0.038 & -0.0382 & 0.052 \\
\hline 2-person family & -0.0944 & 0.033 & 0.0462 & 0.051 \\
\hline 3-person family & -0.203 & 0.038 & -0.0989 & 0.056 \\
\hline 4-person family & -0.222 & 0.042 & -0.0167 & 0.060 \\
\hline 5-person family & -0.253 & 0.047 & 0.0510 & 0.064 \\
\hline$>=6$ person family & -0.190 & 0.059 & 0.144 & 0.079 \\
\hline $30<=$ age $<40$ & 0.192 & 0.032 & 0.261 & 0.044 \\
\hline $40<=$ age $<50$ & 0.0796 & 0.020 & 0.0811 & 0.026 \\
\hline $50<=$ age $<60$ & 0.0091 & 0.021 & 0.0127 & 0.027 \\
\hline $60<=$ age $<70$ & 0.0512 & 0.025 & -0.0361 & 0.038 \\
\hline age $>=70$ & -0.147 & 0.033 & -0.245 & 0.056 \\
\hline $2^{\text {nd }}$ quartile earnings & 0.362 & 0.022 & 0.511 & 0.037 \\
\hline $3^{\text {rd }}$ quartile earnings & 0.256 & 0.023 & 0.516 & 0.036 \\
\hline $4^{\text {th }}$ quartile earnings & -0.0124 & 0.026 & 0.439 & 0.039 \\
\hline $2^{\text {nd }}$ quartile wealth income & -0.0171 & 0.013 & -0.0237 & 0.022 \\
\hline $3^{\text {rd }}$ quartile wealth income & 0.0115 & 0.015 & 0.0546 & 0.024 \\
\hline $4^{\text {th }}$ quartile wealth income & 0.0905 & 0.016 & 0.199 & 0.026 \\
\hline $2^{\text {nd }}$ quartile transfer income & -0.0075 & 0.025 & -0.153 & 0.037 \\
\hline $3^{\text {rd }}$ quartile transfer income & -0.0091 & 0.027 & -0.169 & 0.046 \\
\hline $4^{\text {th }}$ quartile transfer income & -0.0896 & 0.030 & -0.267 & 0.046 \\
\hline $2^{\text {nd }}$ quartile retirement inc. & -0.0842 & 0.037 & -0.219 & 0.070 \\
\hline $3^{\text {rd }}$ quartile retirement inc. & -0.0303 & 0.037 & -0.116 & 0.079 \\
\hline $4^{\text {th }}$ quartile retirement inc. & -0.0768 & 0.033 & -0.193 & 0.074 \\
\hline Eastern Europe & 0.0500 & 0.053 & 0.0774 & 0.056 \\
\hline Mexican & -0.230 & 0.062 & -0.306 & 0.073 \\
\hline Other Spanish & -0.171 & 0.050 & -0.165 & 0.061 \\
\hline African-American & -0.466 & 0.064 & -0.582 & 0.097 \\
\hline Other ethnic groups & -0.0164 & 0.022 & -0.0455 & 0.026 \\
\hline State GDP growth rate & -0.156 & 0.25 & -0.322 & 0.44 \\
\hline State unemployment rate & 1.83 & 0.78 & 2.39 & 1.1 \\
\hline Non-farming employment & -0.391 & 0.19 & -0.310 & 0.22 \\
\hline Max state income tax rate & 0.924 & 0.33 & 0.644 & 0.40 \\
\hline Constant & -1.90 & 0.20 & -2.75 & 0.24 \\
\hline
\end{tabular}


Table 2:

Predicted Probabilities of Owning Businesses

\begin{tabular}{|l|c|c|c|c|}
\hline $\begin{array}{l}\text { Exemption } \\
\text { Category }\end{array}$ & $\begin{array}{c}\text { Own any } \\
\text { business }\end{array}$ & $\begin{array}{c}\text { Own “big” } \\
\text { business }\end{array}$ & $\begin{array}{c}\text { Own } \\
\text { non-corporate } \\
\text { business }\end{array}$ & $\begin{array}{c}\text { Own } \\
\text { corporate } \\
\text { business }\end{array}$ \\
\hline Owners & $(1)$ & $(2)$ & $(3)$ & $(4)$ \\
\hline $1^{\text {st }}$ quartile & .101 & .0470 & .0796 & .0258 \\
\hline $2^{\text {nd }}$ quartile & .103 & .0446 & .0784 & .0261 \\
\hline $3^{\text {rd }}$ quartile & $.110^{*}$ & .0481 & $.0872^{*}$ & .0246 \\
\hline $4^{\text {th }}$ quartile & $.114^{*}$ & .0517 & $.101^{*}$ & $.0200^{*}$ \\
\hline Unlimited & $.135^{*}$ & $.0600^{*}$ & $.110^{*}$ & $.0294^{*}$ \\
\hline Renters & & .0347 & .0534 & .0188 \\
\hline $1^{\text {st }}$ quartile & .083 & .0347 & .0706 & .0218 \\
\hline $2^{\text {nd }}$ quartile & .086 & .0417 & $.0710^{*}$ & .0134 \\
\hline $3^{\text {rd }}$ quartile & .094 & .0354 & $.0734^{*}$ & $.0126^{*}$ \\
\hline $4^{\text {th }}$ quartile & .086 & .0356 & $.0434^{*}$ & .0183 \\
\hline Unlimited & $.107^{*}$ & .0447 & & \\
\hline
\end{tabular}

Notes: Asterisks indicate that the variable is significantly higher than the $1^{\text {st }}$ quartile level for homeowners or renters, whichever is relevant. Columns (1) and (2) are based on the random effects probit models reported in table 1. Columns (3) and (4) are based on multi-nomial logit models of the decision to own non-corporate businesses, corporate businesses, or no business (full results not reported). 


\section{Table 3. Effect of Bankruptcy on Whether Families Start and End Businesses}

\begin{tabular}{|c|c|c|c|c|}
\hline & \multicolumn{2}{|c|}{ Start businesses } & \multicolumn{2}{|c|}{ End businesses } \\
\hline Explanatory Variables & Coef. & s.e. & Coef. & s.e. \\
\hline $1^{\text {st }}$ quartile - owner & 0.0669 & 0.066 & -0.313 & 0.13 \\
\hline $2^{\text {nd }}$ quartile - renter & -0.0916 & 0.075 & -0.354 & 0.14 \\
\hline $2^{\text {nd }}$ quartile - owner & 0.0117 & 0.065 & -0.240 & 0.13 \\
\hline $3^{\text {rd }}$ quartile - renter & -0.0238 & 0.076 & 0.0624 & 0.14 \\
\hline $3^{\text {rd }}$ quartile - owner & 0.0839 & 0.066 & -0.265 & 0.13 \\
\hline $4^{\text {th }}$ quartile - renter & 0.147 & 0.076 & -0.0074 & 0.15 \\
\hline $4^{\text {th }}$ quartile - owner & 0.150 & 0.072 & -0.226 & 0.13 \\
\hline Unlimited - renter & 0.0589 & 0.080 & 0.0867 & 0.15 \\
\hline Unlimited - owner & 0.158 & 0.068 & -0.195 & 0.13 \\
\hline Number of earners & 0.0174 & 0.023 & 0.106 & 0.052 \\
\hline Live in a metropolitan area & -0.0535 & 0.031 & 0.106 & 0.052 \\
\hline Education level & 0.0137 & 0.0031 & -0.0049 & 0.0060 \\
\hline Single female head & -0.245 & 0.047 & 0.236 & 0.087 \\
\hline Married head & 0.0272 & 0.060 & -0.0450 & 0.10 \\
\hline 2-person family & 0.0264 & 0.053 & 0.108 & 0.093 \\
\hline 3-person family & 0.0586 & 0.061 & 0.146 & 0.10 \\
\hline 4-person family & 0.0826 & 0.065 & 0.147 & 0.11 \\
\hline 5-person family & 0.0927 & 0.074 & 0.135 & 0.12 \\
\hline 6 more person family & 0.0727 & 0.090 & 0.149 & 0.14 \\
\hline $30<=$ age $<40$ & 0.0132 & 0.044 & -0.348 & 0.086 \\
\hline $40<=$ age $<50$ & -0.0382 & 0.035 & -0.0869 & 0.054 \\
\hline $50<=$ age $<60$ & -0.0499 & 0.042 & -0.0516 & 0.062 \\
\hline $60<=$ age $<70$ & -0.227 & 0.058 & 0.164 & 0.091 \\
\hline Age $>=70$ & -0.326 & 0.064 & 0.124 & 0.10 \\
\hline $2^{\text {nd }}$ quartile earnings & -0.0636 & 0.043 & -0.0655 & 0.088 \\
\hline $3^{\text {rd }}$ quartile earnings & -0.117 & 0.047 & -0.135 & 0.13 \\
\hline $4^{\text {th }}$ quartile earnings & -0.138 & 0.055 & -0.112 & 0.18 \\
\hline $2^{\text {nd }}$ quartile wealth income & 0.0293 & 0.036 & -0.0660 & 0.57 \\
\hline $3^{\text {rd }}$ quartile wealth income & 0.0075 & 0.039 & -0.126 & 0.056 \\
\hline $4^{\text {th }}$ quartile wealth income & 0.0574 & 0.041 & -0.133 & 0.056 \\
\hline $2^{\text {nd }}$ quartile transfer income & -0.0697 & 0.055 & 0.414 & 0.088 \\
\hline $3^{\text {rd }}$ quartile transfer income & -0.0888 & 0.060 & 0.389 & 0.093 \\
\hline $4^{\text {th }}$ quartile transfer income & 0.0121 & 0.059 & 0.244 & 0.10 \\
\hline $2^{\text {nd }}$ quartile retirement inc. & 0.0814 & 0.072 & 0.237 & 0.12 \\
\hline $3^{\text {rd }}$ quartile retirement inc. & 0.0098 & 0.081 & 0.183 & 0.12 \\
\hline $4^{\text {th }}$ quartile retirement inc. & -0.128 & 0.089 & 0.0479 & 0.12 \\
\hline Eastern Europe & 0.0140 & 0.068 & -0.0552 & 0.13 \\
\hline Mexican & -0.225 & 0.085 & 0.0627 & 0.14 \\
\hline Other Spanish & -0.116 & 0.064 & -0.0677 & 0.11 \\
\hline African-American & -0.374 & 0.081 & 0.189 & 0.15 \\
\hline State unemployment rate & 1.67 & 1.6 & 5.77 & 2.3 \\
\hline Non-farming employment & 0.000 & 0.000 & 0.000 & 0.000 \\
\hline Max state income tax rate & 0.279 & 0.469 & 1.01 & 0.73 \\
\hline Constant & -2.30 & 0.14 & -0.817 & 0.25 \\
\hline
\end{tabular}


Table 4:

Predicted Probabilities of Starting and Ending Businesses

\begin{tabular}{|c|c|c|}
\hline $\begin{array}{c}\text { Exemption } \\
\text { Category }\end{array}$ & $\begin{array}{c}\text { Start business } \\
\text { (random-effect probit model) }\end{array}$ & $\begin{array}{c}\text { End business } \\
\text { (random-effect probit model) }\end{array}$ \\
\hline Owners & $(1)$ & $(2)$ \\
\hline $1^{\text {st }}$ quartile & .0226 & .141 \\
\hline $2^{\text {nd }}$ quartile & .0198 & .157 \\
\hline $3^{\text {rd }}$ quartile & .0234 & .151 \\
\hline $4^{\text {th }}$ quartile & .0272 & .160 \\
\hline Unlimited & .0277 & .167 \\
\hline Renters & .0193 & .219 \\
\hline $1^{\text {st }}$ quartile & .0155 & .132 \\
\hline $2^{\text {nd }}$ quartile & .0183 & .237 \\
\hline $3^{\text {rd }}$ quartile & .0270 & .217 \\
\hline $4^{\text {th }}$ quartile & .0221 & \\
\hline Unlimited & & \\
\hline
\end{tabular}

Notes: Asterisks indicate that the variable is significantly higher than the $1^{\text {st }}$ quartile level for homeowners or renters, whichever is relevant. Figures are based on the random effects probit models reported in table 3 . 
Table A1. Summary Statistics

\begin{tabular}{|c|c|c|}
\hline & \multicolumn{2}{|c|}{$\begin{array}{c}\text { SIPP } \\
1993-95 \text { and 1996-98 panels }\end{array}$} \\
\hline & (1) & $(2)$ \\
\hline & Mean & s.d. \\
\hline Own business & .110 & .313 \\
\hline Start business & .0299 & .170 \\
\hline End business & .0294 & .169 \\
\hline Own incorporated business & .0330 & .178 \\
\hline Exemption $(000 \$)$ & 62.8 & 71.8 \\
\hline Unlimited exemption & .182 & .386 \\
\hline $1^{\text {st }}$ quartile - renter/owner & $.064 / .136$ & $.245 / .343$ \\
\hline $2^{\text {nd }}$ quartile - renter/owner & $.068 / .152$ & $.252 / .359$ \\
\hline $3^{\text {rd }}$ quartile - renter/owner & $.065 / .155$ & $.247 / .362$ \\
\hline $4^{\text {th }}$ quartile - renter/owner & $.060 / .118$ & $.237 / .323$ \\
\hline Unlimited - renter/owner & $.054 / .128$ & $.226 / .334$ \\
\hline Business income/month (\$) & 2,385 & $\$ 4,368$ \\
\hline Number of earners & 1.15 & .924 \\
\hline Metropolitan area & .772 & .419 \\
\hline Own their home & .689 & .463 \\
\hline Education level & 9.33 & 9.00 \\
\hline Single female head & .286 & .452 \\
\hline Married head & .551 & .497 \\
\hline Family size & 2.45 & 1.42 \\
\hline Head's age & 49.8 & 16.8 \\
\hline Log earnings & 7.87 & .95 \\
\hline Wealth income/month (\$) & 156 & 640 \\
\hline Transfer income/month (\$) & 212 & 569 \\
\hline Retirement income/month (\$) & 147 & 582 \\
\hline Eastern Europe & .0350 & .184 \\
\hline Mexican & .0315 & .175 \\
\hline Other Spanish & .0453 & .208 \\
\hline African-American & .0593 & .236 \\
\hline Other ethnic groups & .355 & .478 \\
\hline State GDP growth rate & .0273 & .0149 \\
\hline State unemployment rate & .0554 & .014 \\
\hline Non-farming employment share & .886 & .061 \\
\hline Max. state income tax rate & .0556 & .032 \\
\hline Own "big” business & .049 & .216 \\
\hline "Big" business income/month (\$) & 5,727 & 6,104 \\
\hline
\end{tabular}

